

\title{
Growth, Yield and Economics of Maize (Zea mays L.) Varieties under Front Line Demonstrations in Ganderbal, Jammu and Kashmir
}

\author{
Javid Ahmad Bhat ${ }^{1}$, Eajaz Ahmad Dar ${ }^{1 *}$, K. A. Dar ${ }^{2}$, Zahida Rashid ${ }^{3}$, F. A. Ahanger ${ }^{1}$, \\ S. A. Banday ${ }^{1}$, P. A. Dar ${ }^{1}$, Bhinish Shakeel ${ }^{1}$ and Sajad Mohi-ud-din Mir ${ }^{1}$
}

${ }^{1}$ Krishi Vigyan Kendra, Ganderbal, Sher-e-Kashmir University of Agricultural Sciences \& Technology of Kashmir, Shuhama Ganderbal, ${ }^{2}$ HMAARI, Leh Stakna, ${ }^{3}$ DARS, Srinagar, India

*Corresponding author




by $29 \%$. The production and productivity during this period has increased by 185 and $120 \%$, respectively (Table 1 ). This has been mainly due to the technological interventions of Krishi Vigyan Kendra, Ganderbal and the district agriculture department.

The rapid adoption of high-yielding/improved maize varieties has led to significant yield increases in the favourable rain-fed and irrigated maize growing areas. In recent years, the majority of farmers in favourable maize growing areas have switched to improved/hybrid varieties for its superior yield and profit, resistance to several biotic and abiotic stresses (Dar et al., 2017; Dar et al., 2014) despite the higher seed cost.

Jammu \& Kashmir, one of the Himalayan states of India, is the traditional maize growing region in the country. Augmentation of maize productivity is imperative for uplifting smallholder farmers in the state. Research \& Development institutions have developed a number of varieties and input technologies for the development of maize sector of the state. Besides, the state government also promotes composite seeds through State Seed Corporation and the promising varieties are generally procured from the private sector.

However, the adoption of improved maize varieties by the farmers is still poor. Intensification in yield by using technical interventions in FLDs plots was reported by Patil et al., (2019) and Teggelli et al., (2018). Higher net returns and benefit cost ratio in demonstration plots as compared to farmer practices was reported by Meena et al., (2018) and Yadav et al., (2020).

Thus in this backdrop, the front line demonstrations were carried out by Krishi Vigyan Kendra Ganderbal to demonstrate the performance of improved maize varieties in the district and to improve the adaptability of high yielding varieties developed by the university.

\section{Materials and Methods}

The front line demonstrations were carried out by Krishi Vigyan Kendra Ganderbal in different villages of the district during the maize growing season of 2017, 2018 and 2019. In total 44 FLDs were carried out on an area of $13.5 \mathrm{ha}$. The varieties demonstrated as per the region adaptability were SMC-4 and SMC-7 and compared with the local check. For carrying out the front line demonstrations, farmers were selected on the basis of interest towards adoption of improved varieties, site of field and technical know-how of farmer. All the necessary inputs were provided to selected farmers and regular visits of scientist to the demonstrated field was carried out. Trainings, grouping meetings and field day were organized from time to time for awareness of technologies among the farmers and to provide remedy to the problems faced by them. The sowing was done in first fortnight of May during all the years. All the improved cultivation practices like fertilizer, herbicide, irrigation and plant protection measures were demonstrated to the farmers as per the recommended guidelines (SKUAST-K package of practices). The yield data was recorded from demonstrated plots as well as farmers' practices plots. Plant height, plant girth, leaf area index, yield, cost of cultivation, gross return, net return and benefit cost ratio were computed and analyzed as per the standard procedures (Dar et al., 2014). T-test was done to compare the demonstrated varieties with the check using Proc GLM procedure and correlation analysis was done to find the correlation of grain yield with growth and yield attributes using Proc CORR procedure of SAS version 9.4 (SAS Institute, Inc., Cary, NC, USA). 


\section{Results and Discussion}

Plant height, Plant girth and leaf area index

The results of Front line demonstrations conducted during the three years in different villages of district Ganderbal using high yielding varieties and improved crop management practices revealed that SMC-7 recorded the plant height, plant growth and leaf area index (LAI) as compared to SMC-4 and check variety (Table 2 ). The mean plant height $(207 \mathrm{~cm})$, plant girth $(7.4 \mathrm{~cm})$ and LAI of demonstration plots (6.8) were significantly higher than the check $(163 \mathrm{~cm}$, $6.6 \mathrm{~cm}$ and 5.8, respectively). On percentage basis, the mean plant height, girth and leaf area index in demonstration plots was 27,12 and $17 \%$ higher than the check variety. An increase in growth attributes by technological interventions was also reported by Dar et al (2018a), Dar et al., (2017a), Dar et al., (2019b) and Yadav et al., (2020).

Table.1 Status of Maize crop in district Ganderbal

\begin{tabular}{|c|c|c|c|c|c|c|}
\hline \multirow{2}{*}{ Crop } & \multicolumn{3}{|c|}{ 2011-12 } & \multicolumn{3}{c|}{ 2018-19 } \\
\cline { 2 - 7 } & $\begin{array}{c}\text { Area } \\
\text { (ha) }\end{array}$ & $\begin{array}{c}\text { Production } \\
(\mathrm{q})\end{array}$ & $\begin{array}{c}\text { Productivity } \\
(\mathrm{q} / \mathrm{ha})\end{array}$ & $\begin{array}{c}\text { Area } \\
(\mathrm{ha})\end{array}$ & $\begin{array}{c}\text { Production } \\
(\mathrm{q})\end{array}$ & $\begin{array}{c}\text { Productivity } \\
(\mathrm{q} / \mathrm{h})\end{array}$ \\
\hline Maize & 5003 & 4373 & 12.9 & 6450 & 12463 & 28.4 \\
\hline
\end{tabular}

Table.2 Effect of varieties on growth attributes of maize, green fodder yield, dry fodder yield and grain yield at harvest under front line demonstration in district Ganderbal (Average of 2017, 2018 and 2019)

\begin{tabular}{|c|c|c|c|c|c|c|c|c|c|c|c|c|c|c|}
\hline \multirow{2}{*}{$\begin{array}{l}\text { Treatment } \\
\text { Variety }\end{array}$} & \multirow[t]{2}{*}{$\begin{array}{l}\text { No. of } \\
\text { Demo. }\end{array}$} & \multirow[t]{2}{*}{$\begin{array}{c}\text { Area } \\
\text { (ha) }\end{array}$} & \multicolumn{2}{|c|}{$\begin{array}{l}\text { Plant height } \\
\text { (cm) }\end{array}$} & \multicolumn{2}{|c|}{$\begin{array}{l}\text { Plant girth } \\
\quad(\mathrm{cm})\end{array}$} & \multicolumn{2}{|c|}{$\begin{array}{l}\text { Leaf area } \\
\text { index }\end{array}$} & \multicolumn{2}{|c|}{$\begin{array}{l}\text { Green fodder } \\
\text { yield (t/ha) }\end{array}$} & \multicolumn{2}{|c|}{$\begin{array}{l}\text { Dry fodder } \\
\text { yield } \\
\text { (t/ha) }\end{array}$} & \multicolumn{2}{|c|}{$\begin{array}{l}\text { Grain yield } \\
\text { (t/ha) }\end{array}$} \\
\hline & & & Demo & Check & Demo & Check & Demo & Check & Demo & Check & Demo & Check & Demo & Check \\
\hline SMC-4 & 29 & 8.5 & 203 & 160 & 7.3 & 6.5 & 6.7 & 5.5 & 30.5 & 20.5 & 6.6 & 5.0 & 4.1 & 2.8 \\
\hline SMC-7 & 15 & 5.0 & 210 & 165 & 7.5 & 6.7 & 6.9 & 6.0 & 32.7 & 20.9 & 7.2 & 4.4 & 5.1 & 3.0 \\
\hline Mean & & & 207 & 163 & 7.4 & 6.6 & 6.8 & 5.8 & 31.6 & 20.7 & 6.9 & 4.7 & 4.6 & 2.9 \\
\hline $\begin{array}{l}\text { Demo vs } \\
\text { Check } \\
(\operatorname{Pr}>[t])\end{array}$ & & & \multicolumn{2}{|c|}{$0.0081 * *$} & \multicolumn{2}{|c|}{$0.0442 *$} & \multicolumn{2}{|c|}{$0.0142 * *$} & \multicolumn{2}{|c|}{$0.0006^{* *}$} & \multicolumn{2}{|c|}{$0.0007 * *$} & \multicolumn{2}{|c|}{$0.0012 * *$} \\
\hline
\end{tabular}

Table.3 Economics of maize varieties under front line demonstration in district Ganderbal (Average of 2017, 2018 and 2019)

\begin{tabular}{|l|c|c|c|c|c|c|c|c|}
\hline Variety & \multicolumn{4}{|c|}{ Economics of demonstration (Rs./ha) } & \multicolumn{3}{c|}{ Economics of check (Rs./ha) } \\
& $\begin{array}{c}\text { Gross } \\
\text { Cost }\end{array}$ & $\begin{array}{c}\text { Gross } \\
\text { Return }\end{array}$ & $\begin{array}{c}\text { Net } \\
\text { Return }\end{array}$ & BCR & $\begin{array}{c}\text { Gross } \\
\text { Cost }\end{array}$ & $\begin{array}{c}\text { Gross } \\
\text { Return }\end{array}$ & $\begin{array}{c}\text { Net } \\
\text { Return }\end{array}$ & BCR \\
\hline SMC-4 & 46800 & 126953 & 80153 & 2.71 & 44500 & 102300 & 57800 & 2.29 \\
\hline SMC-7 & 47300 & 158300 & 111000 & 3.35 & 44000 & 109850 & 65850 & 2.49 \\
\hline
\end{tabular}


Table.4 Correlation of grain yield with other growth and yield attributes

\begin{tabular}{|l|l|l|l|l|l|}
\hline & \multicolumn{5}{|c|}{ Pearson Correlation Coefficients: Prob $>|\mathbf{r}|$ under H0: Rho=0 } \\
\hline & Plant height & Plant girth & $\begin{array}{l}\text { Leaf area } \\
\text { index }\end{array}$ & $\begin{array}{l}\text { Green fodder } \\
\text { yield }\end{array}$ & $\begin{array}{l}\text { Dry fodder } \\
\text { yield }\end{array}$ \\
\hline Grain Yield & $0.98^{* *}$ & $0.83^{*}$ & $0.77^{*}$ & $0.95^{* *}$ & $0.95^{* *}$ \\
\hline
\end{tabular}

\section{Green fodder yield and dry fodder yield}

The green fodder yield and dry fodder yield was higher in SMC-7 as compared to SMC-4 and check variety. The mean green fodder yield of demonstration plots (31.6 t/ha) was significantly higher than the check varieties $(20.7 \mathrm{t} / \mathrm{ha}$ ) by $53 \%$, while as the dry fodder yield was significantly higher by $47 \%$. The increase in fodder yield may be attributed to better growth attributes of the demonstrated varieties (Table 2). An increase in yield attributes by technological interventions was also reported by Dar et al., (2018b), Kumari et al., (2014) and Yadav et al., (2020).

\section{Grain yield}

The results of Front line demonstrations conducted during 2017- 2019 in different villages of district Ganderbal using high yielding varieties and improved crop management practices revealed that SMC-7 recorded the highest grain yield of $5.1 \mathrm{t} / \mathrm{ha}$ as compared to the yield of $3.0 \mathrm{t} / \mathrm{ha}$ by the check variety (Table 2). The yield was $68 \%$ higher than the check variety. SMC-4 also resulted in higher yield (4.1 t/ha) than the check varieties $(2.8 \mathrm{t} / \mathrm{ha})$. The mean grain yield of $4.6 \mathrm{t} / \mathrm{ha}$ was significantly higher than the check variety $(2.9 \mathrm{t} / \mathrm{ha}$ ) by $59 \%$. An increase in yield by technological interventions in FLDs may be attributed to the provision of better environment and availability of inputs to the crop in right amount and at right time together with adoption of high yielding varieties. An increase in yield by technological interventions was also reported by Singh and Bisen (2020), Dar et al., (2017b), Dar et al., (2019a), Kumari et al., (2014) and the farmers are thus advised to cultivate SMC-7 variety as compared to the local landraces.

\section{Economics}

The economics of different maize varieties under front line demonstrations revealed that SMC-7 is best with a net income of Rs. $111,000 /$ ha and a benefit cost ratio of 3.35 as compared to the net returns of Rs. $65,850 /$ ha in check plot, which was $41 \%$ lower than SMC-7. The net returns in SMC-4 were Rs. 80,153 which was $39 \%$ higher yield than the check (Table 3). The higher net returns and benefit cost ratio may be attributed to higher yield in the demonstration plots as compared to the check. Similarly increase in income with adoption of improved cultivation practices was also reported by Yadav et al., (2020) and Singh and Bisen (2020).

\section{Correlation analysis}

The correlation analysis of plant height, plant girth, LAI, green and dry fodder yield with grain yield (Table 4) revealed that all these attributes have significant positive effect on grain yield. This means that more the plant height, girth, LAI, green and dry fodder yield, higher will be the grain yield. The maximum correlation for grain yield was found with plant height $(\mathrm{r}=0.98)$ followed by green fodder yield $(\mathrm{r}=0.95)$, dry fodder yield $(\mathrm{r}=0.95)$ plant girth $(\mathrm{r}=0.83)$ and LAI $(\mathrm{r}=0.77)$.

From the study it can be concluded that adoption of high yielding varieties like SM-7 
together with recommended cultivation practices resulted in an increase in the yield and monetary income of farmer and thus need to be adopted by the farmers.

\section{References}

Baba, S.H., Mir, S.A. 2018. Maize based farming system S\&T interventions in agricultural \& allied sectors for strengthening livelihood security in Kashmir Division. Final Report of NSTMIS DST research project, Supplement \# 02. Sher-e-Kashmir University of Agricultural Sciences \& Technology of Kashmir, Shalimar Campus, Srinagar (J\&K).

Dar, A.S., Rather, B.A., Wani, G.A., Ganie, M.A. 2017. Resistance against insect pests by plant phenolics and their derivative compounds. Chemical Science Review and Letters 6: $1073-$ 1081.

Dar, E.A., Brar, A.S., Yousuf, A. 2018b. Growing degree days and heat use efficiency of wheat as influenced by thermal and moisture regimes. Journal of Agrometeorology 20: 168-170.

Dar, E.A., Brar, A.S., Mishra, S.K., Singh, K.B. 2017a. Simulating response of wheat to timing and depth of irrigation water in drip irrigation system using CERES-Wheat model. Field Crops Research 214: 149-163.

Dar, E.A., Brar, A.S., Mushtaq, A., Amin, M., Todarmal, P. 2019b. Growth, yield and economics of drip-irrigated wheat (Triticum aestivum) as influenced by timing and depth of irrigation water application. Indian Journal of Agronomy 64: 29-36.

Dar, E.A., Brar, A.S., Singh, K.B. 2017 b. Water use and productivity of drip irrigated wheat under variable climatic and soil moisture regimes in NorthWest, India. Agriculture, Ecosystem and Environment 248: 9-19.

Dar, E.A., Brar, A.S., Todarmal, P., Amin, M. 2019a. Growing degree days and heat use efficiency of wheat as influenced by thermal and moisture regimes. Indian Journal of Agronomy 64: 218225.

Dar, E.A., Harika, A.S., Datta, A., Jat, H.S. 2014. Growth, yield and economic returns from the dual purpose baby corn (Zea mays) under different planting geometry and nitrogen levels. Indian Journal of Agronomy 59: 468470.

Dar, E.A.., Mehdi M., Ahmad M., Hussain N., Hussain M., Bhat, F.N., Mushtaq T., Dolkar D., Bahar F.A. 2018a. Evaluation of Barley Genotypes under Cold Arid Conditions of KargilLadakh. Research Journal of Chemical and Environmental Sciences 6: 22-24.

Dar, S.A., Mir, Nisar, A.D.., Mudasir, A.B., Mudasir, H.B. 2014. Prospects, utilization and challenges of botanical pesticides in sustainable agriculture. International Journal of Molecular Biology and Biochemistry 1: 1-14.

J\&K, Envis Newsletter, 2017. State of Environment \& its Related Issues in J\&K.. Department of Ecology, Environment \& Remote Sensing, Jammu \& Kashmir. J\&K ENVIS Hub (4) 1:1-16.

Kumari, A., Kumar P, Dar, E.A., Singh M., Kumar R., Yadav R.K., Datt, C., Chinchmalatpure, A. 2014. Fodder yield and quality of oats fodder (Avena sativa) as influenced by salinity of irrigation water and applied nitrogen levels. Indian Journal of Animal Nutrition 31: 266-271.

Meena, R., Singh, B., Meena, K.C., Meena, R.K., Singh B and Gurjar P. 2018. Performance of frontline demonstration on Sesamum (Sesamum 
indicum L.) in Karauli district of Rajasthan, India. International Journal of Current Microbiology and Applied Sciences 7: 1507-1511.

Patil, S.S., Mahalee, M.M., and Chavan, S.S. 2019. Impact of frontline demonstrations (FLDs) on oilseed crops in south Konkan Coastal zone of Maharashtra. Current Agricultural Research Journal 6: 355-364.

Shaheen, F.A., Shabir, A., Wani, G.A., Parray, N.R., Sofi, M., Anwar Bhat, Tariq Sultan, Mohiddin, F.A., Jibran, S., Akhter, N., Naqash, F. and Jeelani F. 2018. Sustaining Rice Farming in Kashmir Valley: Challenges and Opportunities. Agro Economist-An International Journal 5: 61-70.

Singh, N.K., and Bisen, N.K. 2020. Effect of Integrated Crop Management Practices on Yield and Economics of
Brinjal in Seoni district of Madhya Pradesh. Journal of Krishi Vigyan 8: 65-69.

Teggelli, R.G., Suresh, S.M., Zaheer Ahamed, B., and Patil, M.C. 2018. Evaluation of frontline demonstration of Sesamum for sustainable food production in Kalaburagi district of Karnataka. International Journal of Food Science and Nutrition 3: 165167.

USDA-FAS. Corn Area, Yield and Production, 2013. Available at www.fas.usda.gov /psdonline/.

Yadav, N.K., Tiwari, D., Pandey, N.K., Ahmed, M., Devi Sarita, Dixit, A., and Chauhan, A.K. 2020. Impact of front line demonstration on sesamum crop in Lalitpur district of Bundelkhand region. Journal of Krishi Vigyan 8: 182-185.

\section{How to cite this article:}

Javid Ahmad Bhat, Eajaz Ahmad Dar, K. A. Da, Zahida Rashid, F. A. Ahanger, S. A. Banday, P. A. Dar, Bhinish Shakeel and Sajad Mohi-ud-din Mir. 2020. Growth, Yield and Economics of Maize (Zea mays L.) Varieties under Front Line Demonstrations in Ganderbal, Jammu and Kashmir. Int.J.Curr.Microbiol.App.Sci. 9(12): 2750-2755. doi: https://doi.org/10.20546/ijcmas.2020.912.328 